\title{
Metabolic Demand, Oxygen Supply, and Critical Temperatures in the Antarctic Bivalve Laternula elliptica
}

\author{
Lloyd S. Peck ${ }^{1, *}$ \\ Hans O. Pörtner ${ }^{2}$ \\ Iris Hardewig ${ }^{2, \dagger}$ \\ ${ }^{1}$ National Environment Research Council British Antarctic \\ Survey, High Cross, Madingley Road, Cambridge CB3 0ET, \\ United Kingdom; ${ }^{2}$ Alfred Wegener Institut für Polar und \\ Meeresforschung, Biologie I/Ökophysiologie, D-27515 \\ Bremerhaven, Germany
}

Accepted 2/8/02

\begin{abstract}
Oxygen consumption $\left(\dot{M O}_{2}\right)$, heartbeat rate and form, and circulating hemolymph oxygen content were measured in relation to temperature in the large Antarctic infaunal bivalve Laternula elliptica. After elevations in temperature from $0^{\circ}$ to $3^{\circ}, 6^{\circ}$, and then $9^{\circ} \mathrm{C}, \dot{M o}_{2}$ and heartbeat rate rose to new levels, whereas maximum circulating hemolymph oxygen content fell. At $0^{\circ} \mathrm{C}$, $\dot{\mathrm{Mo}}_{2}$ was $19.6 \mu \mathrm{mol} \mathrm{O} \mathrm{h}^{-1}$ for a standard animal of 2-g tissue ash-free dry mass, which equates to a 8.95 -g tissue dry-mass or 58.4-g tissue wet-mass animal. Elevation of metabolism following temperature change had acute $\mathrm{Q}_{10}$ values between 4.1 and 5, whereas acclimated figures declined from 3.4 (between $0^{\circ}$ and $\left.3^{\circ} \mathrm{C}\right)$ to $2.2\left(3^{\circ}-6^{\circ} \mathrm{C}\right)$ and $1.9\left(6^{\circ}-9^{\circ} \mathrm{C}\right)$. Heartbeat rate showed no acclimation following temperature elevations, with $\mathrm{Q}_{10}$ values of 3.9, 3.2, and 4.3, respectively. Circulating hemolymph oxygen content declined from $0^{\circ}$ to $3^{\circ}$ and $6^{\circ} \mathrm{C}$ but stayed at a constant $\mathrm{Po}_{2}(73-78 \mathrm{mmHg})$ and constant proportion $(\sim 50 \%)$ of the oxygen content of the ambient water. At $9^{\circ} \mathrm{C}$, $\dot{\mathrm{Mo}}_{2}$ and heartbeat rate both peaked at values 3.3 times those measured at $0^{\circ} \mathrm{C}$, which may indicate aerobic scope in this species. After these peaks, both measures declined rapidly over the ensuing $5 \mathrm{~d}$ to the lowest measured in the study, and the bivalves began to die. Hemolymph oxygen content fell dramatically at $9^{\circ} \mathrm{C}$ to values between $2 \%$ and $12 \%$ of ambient water $\mathrm{O}_{2}$ content and had a maximum $\mathrm{Po}_{2}$ of around $20 \mathrm{mmHg}$. These data indicate an experimental upper lethal temperature of $9^{\circ} \mathrm{C}$ and a critical temperature, where a long-term switch to
\end{abstract}

\footnotetext{
*Corresponding author; e-mail: 1.peck@bas.ac.uk.

${ }^{\dagger}$ Present address: Institute of Freshwater Ecology and Inland Fisheries, Müggelseedamm 310, 2578 Berlin, Germany.
}

Physiological and Biochemical Zoology 75(2):123-133. 2002. (C) 2002 by The University of Chicago. All rights reserved. 1522-2152/2002/7502-0086\$15.00 anaerobic metabolism probably occurs, of around $6^{\circ} \mathrm{C}$ for $L$. elliptica. Concurrent measures of mitochondrial function in the same species had indicated strong thermal sensitivity in proton leakage costs, and our data support the hypothesis that as temperature rises, mitochondrial maintenance costs rapidly outstrip oxygen supply mechanisms in cold stenothermal marine species.

\section{Introduction}

Polar marine ectotherms are at one end of the temperature continuum for life in the oceans. They can generally only survive at low temperatures, and within small temperature ranges, they are highly stenothermal (Somero et al. 1996, 1998; Peck and Conway 2000). This trait has come from evolution to a very stable temperature environment and carries with it many specific biochemical and physiological adaptations. These include the possession of enzymes with increased activity at low temperatures, larger quantities of key enzymes, and mitochondrial proliferation (Clarke 1998).

Recently, there has been significant interest in physiological adaptation to low temperatures (e.g., Johnston and Bennet 1996; Pörtner and Playle 1998) and the mechanisms limiting tolerance to elevated or reduced temperatures. As lethal temperature limits are approached, a transfer to anaerobic metabolism has been identified in temperate and polar species, and this transfer has been termed the "critical temperature" (Zielinski and Pörtner 1996; Pörtner et al. 1998, 2000). These critical temperatures probably indicate long-term lethal limits. In a study of the Weddell Sea bivalve Limopsis marionensis, Pörtner et al. $(1999 b)$ found a critical temperature around $2{ }^{\circ} \mathrm{C}$, indicating transition to a time-limited situation. Fifty percent mortality occurred within $10 \mathrm{~d}$ of exposure at $4.0^{\circ} \mathrm{C}$. At temperatures of $2^{\circ} \mathrm{C}$ and above, the anaerobic end products succinate and acetate accumulated in mantle tissue and were not reduced to control levels even after $14 \mathrm{~d}$ of exposure. ATP and levels of the Gibbs free-energy change of ATP hydrolysis also decreased and did not recover over this time. The long-term temperature envelope where L. marionensis are capable of physiological homeostasis is, therefore, between $-2^{\circ}$ and $+2^{\circ} \mathrm{C}$, making this possibly the most stenothermal marine invertebrate so far reported.

Later investigations centered on other mechanisms associated with setting temperature limits for polar ectotherms, with a 
focus on mitochondrial contributions to metabolic costs in the large infaunal Antarctic bivalve Laternula elliptica (Pörtner et al. 1999b). Maximum mitochondrial capacity, state 3 mitochondrial respiration, and the costs of proton leakage in mitochondria were assessed in relation to temperature. Costs of proton leakage through inner mitochondrial membranes were assessed as the rate of oxygen consumption by mitochondria during the blockage of oxidative phosphorylation at high phosphorylation potentials by oligomycin (state $4+$ respiration). State 3 respiration and proton leakage costs rose exponentially with temperature, and an unusually high sensitivity to temperature was found for proton leakage. This high thermal sensitivity of proton leakage caused a progressively increasing mitochondrial oxygen demand, which was thought to set upper temperature limits when it exceeded the whole-animal capacity for oxygen uptake and supply.

This study was aimed at evaluating changes in whole-animal oxygen consumption and in mechanisms of physiological oxygen supply in relation to temperature in L. elliptica. Experiments were conducted at the same time on specimens from the same population as for the assessment of mitochondrial capacity and costs. Whole-animal oxygen consumption, heartbeat rate and form, and circulating hemolymph oxygen content were measured to provide a detailed description of oxygen supply in relation to temperature stress.

Laternula elliptica was chosen because it is a common, large infaunal bivalve with easily accessible nearshore populations. It has a circumAntarctic distribution, and much of its general ecology, including feeding, routine metabolism, and growth rate, have been previously investigated (Ralph and Maxwell 1977a; Ahn 1994, 1997; Brey and Mackensen 1997; Ahn and Shim 1998). Also, tissue volumes are large enough to allow extraction of sufficient mitochondria to allow accurate measurement of mitochondrial function, and the animal is large enough to facilitate the collection of hemolymph samples for oxygen analysis.

\section{Material and Methods}

Laternula elliptica specimens were collected from North Bay, Rothera Point, Adelaide Island $\left(67^{\circ} 34^{\prime} \mathrm{S}, 68^{\circ} 08^{\prime} \mathrm{W}\right)$, from a softsediment site at a depth of $29-33 \mathrm{~m}$ by scuba divers in November 1997. The sea temperature during the preceding $2 \mathrm{wk}$ had been in the range of $-1.0^{\circ}$ to $-0.2^{\circ} \mathrm{C}$. The specimens were transferred to buckets in the sea and transported $0.8 \mathrm{~km}$ to the Bonner Laboratory (Rothera station) marine aquarium, underwater at all times. In the aquarium, they were held in a throughflow seawater system at temperatures between $-0.6^{\circ}$ and $+0.4^{\circ} \mathrm{C}$ (temperatures were continuously logged) for between 5 and $8 \mathrm{~d}$ before the initiation of experiments.

The experimental system was comprised of a jacketed water bath connected to a thermostatically controlled water heater/ chiller. Animals were placed in the inner 175-L compartment, and temperature-controlled water passed through the outer jacket. The whole system was held in a controlled temperature room. Using this system, seawater temperature in the experiments was controlled to a maximum variation of $\pm 0.2^{\circ} \mathrm{C}$. Initially, 19 specimens were placed in the system, and three were replaced after $5 \mathrm{~d}$; five were used to measure oxygen consumption, four for heartbeat assessments, and 13 for hemolymph oxygen content. A control group of 15 specimens was held without food in the main aquarium system for over $50 \mathrm{~d}$ with no mortality. It is therefore unlikely that starvation had a large effect in these experiments. That cold-water species can survive long periods of starvation, over $100 \mathrm{~d}$, with little obvious effect has been demonstrated for the limpet Nacella concinna and the brachiopod Liothyrella uva (Peck 1989), and it has been demonstrated for over $120 \mathrm{~d}$ for the urchin Sterechinus neumayeri (Brockington and Clarke 2001) and for over $60 \mathrm{~d}$ for the bivalve Limopsis marionensis (Pörtner et al. 1999b). However, starvation tends to reduce metabolic rates while elevated temperature raises them. Peck (1989) showed that starvation may continue to reduce metabolic rates for at least $25-30 \mathrm{~d}$ before standard levels are reached in L. uva and N. concinna. Measured metabolic rates at a given temperature may therefore be slightly different from those reported here in recently fed animals.

\section{Oxygen Consumption and Hemolymph Oxygen Measures}

Closed-bottle respirometry methods were used. Experimental animals were carefully placed inside 2 -L glass chambers within the controlled temperature system, keeping the Laternula underwater at all times. Chambers were then sealed, and the animals were incubated for variable amounts of time. Incubations were ended when oxygen content of the chambers had been depleted by between $10 \%$ and $20 \%$. Oxygen consumption of the bivalves was calculated by comparison with parallel incubations of identical control chambers with no animal. The oxygen content of the water in chambers was measured using 25$\mu \mathrm{L}$ samples injected into a couloximeter (Peck and Uglow 1990). The syringe was fitted with a Chaney adaptor and was calibrated weekly from samples $(N=10)$ weighed on a microbalance. At the end of the respirometry trials, animal volume was measured by displacement, and this was allowed for in the calculation of respirometer volume. The same five specimens were used throughout the temperature trials. Oxygen consumption was monitored following a temperature rise, and a further rise in temperature was implemented only when metabolism had stabilized following the previous rise. The experiment was ended at $9^{\circ} \mathrm{C}$ when over $50 \%$ of the L. elliptica had died (three out of five). Other specimens of L. elliptica collected at the same time and held without food in the station aquarium suffered no mortality in $50 \mathrm{~d}$. It is unlikely, therefore, that starvation played a significant role in the results obtained.

Oxygen content of the hemolymph was measured from sam- 
ples taken with a $25-\mu \mathrm{L}$ gas-tight syringe fitted with a 24 -gauge needle. The needle was passed through the ligament area of the hinge of the Laternula shell. Samples were taken with the intention of analyzing hemolymph from the ventricle and were therefore postbranchial. For each specimen, two- or threehemolymph samples were taken over a 10 -min period, and the bivalve was returned to the station's aquarium holding system. At all times during this process, specimens were kept underwater. Laternula elliptica from which hemolymph samples were taken at $0^{\circ}$ and $3^{\circ} \mathrm{C}$ all survived at least $2 \mathrm{wk}$ in the holding system. At $6^{\circ} \mathrm{C}$, two of the three specimens died within $1 \mathrm{wk}$, and at $9^{\circ} \mathrm{C}$, all specimens returned to the holding system following the removal of hemolymph samples died within $1 \mathrm{wk}$.

\section{Heartbeat Rate Measures}

Heartbeat rates were measured in four specimens using an impedance-based system (Buchan et al. 1988). Electrodes were made from 1-m lengths of tinned copper wire (18 standard wire gauge) by removing the tin coating over the final 2-3 $\mathrm{mm}$. Holes were then carefully drilled through the shells of four Laternula using a 1-mm diameter bit in a modelers drill (RS Components), and electrodes were implanted on either side of the heart. Electrodes were held in place by spreading cyanoacrylate gel adhesive (RS Components) over the shell around where the wire passed through and by holding $\sim 10 \mathrm{~mm}$ of wire in the glue while it set. Measurements were taken on each animal for $1 \mathrm{~h}$ each day, and continuous recordings were made on single individuals for the $12 \mathrm{~h}$ immediately following temperature changes. Implants were made on day 3 of the experiment and were left in place until day 28 when measurements were completed. Electrodes were then removed, and the animals were returned to the aquarium system.

\section{Metabolite Analyses}

Mantle and siphon tissues were dissected from supernumerary specimens after $24 \mathrm{~h}$ at each experimental temperature. Further samples were taken after $3 \mathrm{~d}$ at $9^{\circ} \mathrm{C}$. Another group of specimens was taken to $10.5^{\circ} \mathrm{C}$, and tissue samples were taken after $2 \mathrm{~d}$. Samples were taken from three L. elliptica at each temperature, and the samples were freeze clamped in liquid nitrogen. These samples were held in liquid nitrogen for transport to Germany, where they were later analyzed for succinate content by ionexchange chromatography as described in Pörtner et al. $(1999 b)$.

\section{Animal Biometrics}

At the end of the trials, or immediately upon death at $9^{\circ} \mathrm{C}$, shell length was measured to the nearest $0.1 \mathrm{~mm}$ using vernier callipers. Specimen dry mass was obtained by drying to constant weight at $60^{\circ} \mathrm{C}$, and AFDM is the difference between dry mass and the material remaining following ignition at $475^{\circ} \mathrm{C}$ for 24 h. Data are presented for a standard animal of 2-g tissue AFDM, which was close to the mean for the group studied. Tissuemass values are given in Table 1 .

\section{Results}

Oxygen Consumption

In initial trials to establish the relationship between oxygen consumption $\left(\mathrm{Mo}_{2}\right)$ and ambient water oxygen partial pressure $\left(\mathrm{Po}_{2}\right)$ at $0^{\circ} \mathrm{C}$, an ability to regulate $\mathrm{Mo}_{2}$ down to $\mathrm{Po}_{2}$ values around $60-70 \mathrm{mmHg}$ was found (Fig. 1). Thus, in later trials measuring $\dot{\mathrm{Mo}}_{2}$ in relation to temperature, there was no experimental influence of reduced $\mathrm{Po}_{2}$ because values were not allowed to fall below $120 \mathrm{mmHg}$.

After $5-10 \mathrm{~d}$ acclimation at $0^{\circ} \mathrm{C}$, standard animal $\mathrm{Mo}_{2}$ stabilized at 19-20 $\mu \mathrm{mol} \mathrm{O} \mathrm{O}^{-1}$ (Fig. 2). Following elevations in temperature to $3^{\circ}$ and $6^{\circ} \mathrm{C}$, metabolism rose to new levels. At $3^{\circ} \mathrm{C}, \mathrm{Mo}_{2}$ simply rose to a new level, whereas at $6^{\circ} \mathrm{C}, \dot{\mathrm{Mo}} 2$ rose to a peak after $3 \mathrm{~d}\left(48 \mu \mathrm{mol} \mathrm{O}\right.$ animal $\left.^{-1} \mathrm{~h}^{-1}\right)$; there was then a decline to a lower $\dot{\mathrm{Mo}}_{2}$ rate. At $9^{\circ} \mathrm{C}, \dot{\mathrm{Mo}}_{2}$ rose to a high value of $63 \mu \mathrm{mol} \mathrm{O}$ animal $^{-1} \mathrm{~h}^{-1}$ within $24 \mathrm{~h}$ of the rise in temperature. On successive days, $\dot{\mathrm{Mo}}_{2}$ fell rapidly until, $4 \mathrm{~d}$ later, standard animal $\dot{\mathrm{Mo}}_{2}$ was $15-18 \mu \mathrm{mol} \mathrm{O}$ animal $^{-1} \mathrm{~h}^{-1}$ and was lower than the lowest rates previously recorded (19-20 $\mu \mathrm{mol}$ $\mathrm{O}_{2}$ animal ${ }^{-1} \mathrm{~h}^{-1}$ at $0^{\circ} \mathrm{C}$ ). These low $\mathrm{Mo}_{2}$ rates were recorded for $3 \mathrm{~d}$ before the experiment was terminated when mortality levels passed $50 \%$. Overall temperature had a significant effect on $\dot{M}_{2}$ (repeated measures ANOVA: $F=8.82, P=0.002$,

Table 1: Shell length and mass data for the experimental Laternula elliptica group studied

\begin{tabular}{lr}
\hline Tissue Measured & $\begin{array}{c}\text { Mean Length }(\mathrm{mm}) \\
\text { or Mass }(\mathrm{g}) \pm \mathrm{SE}\end{array}$ \\
\hline Shell length & $74.6 \pm 2.76$ \\
Whole animal (mantle cavity drained, wet mass) & $107.5 \pm 14.50$ \\
Tissue wet mass & $57.2 \pm 9.46$ \\
Tissue dry mass & $8.78 \pm 1.52$ \\
Tissue ash-free dry mass & $1.96 \pm .27$ \\
\hline
\end{tabular}

Note. $N=5$. 


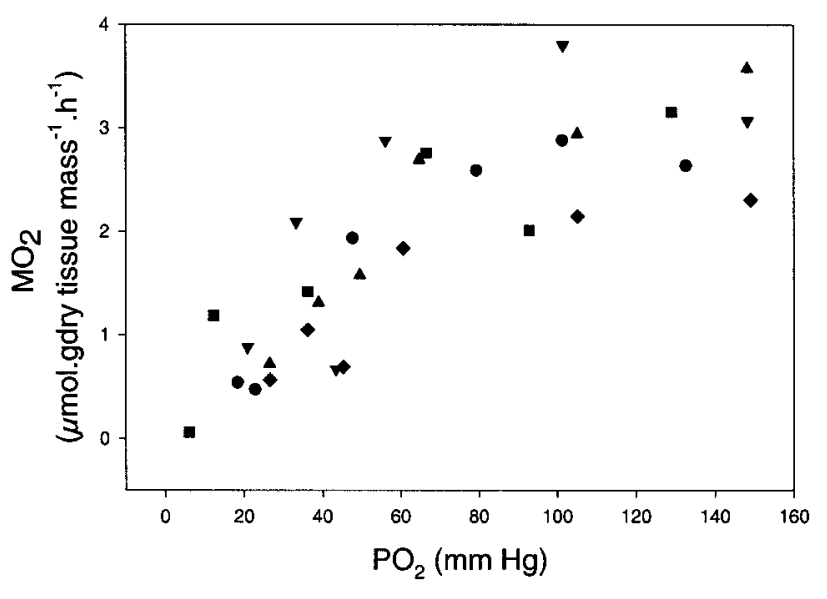

Figure 1. Laternula elliptica oxygen consumption $\left(\mu \mathrm{mol} \mathrm{g}^{-1}\right.$ dry tissue mass $\mathrm{h}^{-1}$ ) in relation to changes in ambient $\mathrm{Po}_{2}(\mathrm{mmHg})$. Data shown are for individuals $(N=5)$ and indicate an ability to regulate oxygen consumption down to ambient $\mathrm{Po}_{2}$ levels of around $60-70 \mathrm{mmHg}$. Trials ran for up to $24 \mathrm{~h}$, and chamber oxygen content was estimated from $25-\mu \mathrm{L}$ samples taken at 3-6-h intervals. Oxygen consumption data are plotted against mean water $\mathrm{Po}_{2}$ for the relevant period.

$N=120) . \dot{M o}_{2}$ at $3^{\circ} \mathrm{C}$ was significantly higher than at $0^{\circ} \mathrm{C}$ (paired $t$-test: $t=8.81, P<0.001, N=66$ ), and values at $6^{\circ} \mathrm{C}$ were higher than at $3^{\circ} \mathrm{C}$ (paired $t$-test: $t=7.45, P<0.001$, $N=70$ ).

Using all data for $0^{\circ}$ and $3^{\circ} \mathrm{C}$, the acclimated $\mathrm{Mo}_{2}$ rate for $6^{\circ} \mathrm{C}$, and $\mathrm{Mo}_{2}$ data for $9^{\circ} \mathrm{C}$ (excluding the initial peak value and the values after metabolic collapse), $\mathrm{Q}_{10}$ values for metabolic change between temperatures were all between 1.9 and 3.4 (Table 2). Acute $\mathrm{Q}_{10}$ values, comparing previously acclimated $\dot{\mathrm{Mo}}_{2}$ with peaks following a temperature rise, were all between 4 and 5 .

\section{Heartbeat Rate}

At $0^{\circ} \mathrm{C}$, which is within the normally experienced temperature range for this species at Rothera, impedance heartbeat traces were typified by long periods (10-75 $\mathrm{min}$ ) of regular oscillation interspersed with blocks of irregular activity (Fig. 3A). These irregularities were observed to be associated with other activity including siphon contraction and protrusion of the foot associated with attempted burrowing movements. Two specimens often exhibited cyclical periodicity in heartbeat traces, with blocks of 8-15 normal heartbeat cycles separated by one or two beats of significantly lower amplitude (Fig. $3 B$ ). It is not known if these cycles were associated with other possible cyclical activity such as cycles in ventilation. One preparation exhibited a distinct biphasic contraction cycle (Fig. 3C). When temperatures were raised, heartbeat traces alternated between periods of low and high amplitude (Fig. 3D), indicating that the animals attempt to regulate hemolymph flow and respond to enhanced temperature-induced metabolic stress. After the move to $3^{\circ} \mathrm{C}$, heartbeat traces returned to normal in $12-24 \mathrm{~h}$; after the move to $6^{\circ} \mathrm{C}$, the return took around $24 \mathrm{~h}$, and no return to normal occurred at $9^{\circ} \mathrm{C}$.

Heartbeat rate showed a similar response to $\dot{M}_{2}$ when temperatures were raised (Fig. 4). However, no pattern of peak followed by acclimation was apparent at any temperature. Values rose from approximately $4 \mathrm{~min}^{-1}$ at $0^{\circ} \mathrm{C}$ to around $6 \mathrm{~min}^{-1}$ at $3^{\circ} \mathrm{C}, 8 \mathrm{~min}^{-1}$ at $6^{\circ} \mathrm{C}$, and to a peak of $13 \mathrm{~min}^{-1}$ at $9^{\circ} \mathrm{C}$. At $0^{\circ}, 3^{\circ}$, and $6^{\circ} \mathrm{C}$, heartbeats stabilized at each new temperature after a period of fluctuation lasting $3-4 \mathrm{~d}$. At $9^{\circ} \mathrm{C}$, heartbeat rate fell continuously for the $5 \mathrm{~d}$ after the peak to low levels, around $2 \mathrm{~min}^{-1}$, when animals began to die.

$\mathrm{Q}_{10}$ values were 3.80 and 3.31 for the temperature rises from $0^{\circ}$ to $3^{\circ} \mathrm{C}$ and $3^{\circ}$ to $6^{\circ} \mathrm{C}$, respectively (Table 2 ). The acute value for $6^{\circ}$ to $9^{\circ} \mathrm{C}$ was 4.46 , and there was no acclimated value.

\section{Hemolymph Oxygen Content}

This method measures total oxygen content, both bound to pigment and unbound, because the $\mathrm{Po}_{2}$ in the desorber (the sample chamber) is close to 0 under normal conditions. Levels of total oxygen content of the hemolymph at $0^{\circ}, 3^{\circ}$, and $6^{\circ} \mathrm{C}$ ranged from $0.01 \mu \mathrm{mol} \mathrm{cm}{ }^{-3}$ to $0.17 \mu \mathrm{mol} \mathrm{cm}{ }^{-3}$ (Fig. 5). The relationship between the maximum observed hemolymph oxygen content and temperature was investigated by regressing the highest two oxygen concentration values against temperature for assessments between $0^{\circ}$ and $6^{\circ} \mathrm{C}$. The highest two

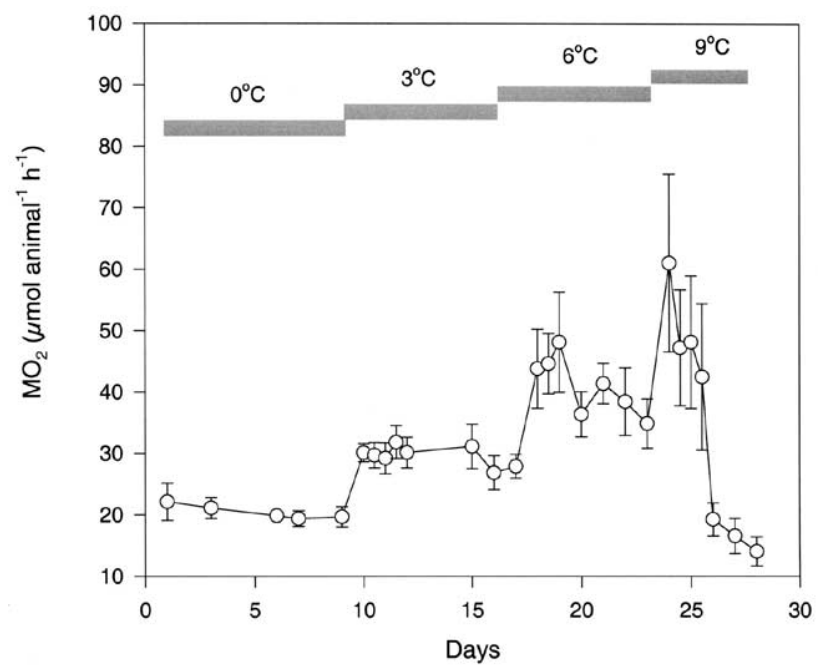

Figure 2. Oxygen consumption $\left(\mu \mathrm{mol} \mathrm{O} \mathrm{h}^{-1}\right)$ of a standard 2-g tissue AFDM Laternula elliptica individual (8.95 g tissue dry mass) in relation to temperature. Data shown are means \pm SE for a group of five individuals recalculated to standard animal values. Bars indicate periods with animals held at the ambient temperature indicated above. 
Table 2: Acute and acclimated $\mathrm{Q}_{10}$ values for Laternula elliptica $\dot{\mathrm{Mo}}_{2}$ and heartbeat rate in response to temperature elevations

\begin{tabular}{llllll}
\hline & \multicolumn{2}{l}{$\dot{M}_{2}$} & & \multicolumn{2}{l}{ Heartbeat Rate } \\
\cline { 2 - 3 } Temperature $\left({ }^{\circ} \mathrm{C}\right)$ & Acute & Acclimated & & Acute & Acclimated \\
\hline $0-3$ & $4.22(.27)$ & $3.39(.21)$ & & $3.80(.20)$ & $3.80(.20)$ \\
$3-6$ & $4.83(.44)$ & $2.24(.36)$ & & $3.31(.66)$ & $3.31(.35)$ \\
$6-9$ & $4.95(.63)$ & N/A & & $4.48(.91)$ & N/A \\
\hline
\end{tabular}

Note. N/A indicates that no stable acclimated rate was obtained after a temperature increment. $\mathrm{Q}_{10}$ values were calculated for each individual, and figures shown are group means $\pm \mathrm{SE}$.

values at each temperature were taken as a measure of maximum hemolymph oxygen content at the sample site. Other values were taken to represent blood at lower oxygen content ranging from partially oxygenated to deoxygenated hemolymph. Maximum hemolymph oxygen content declined linearly with temperature from $0^{\circ}$ to $6^{\circ} \mathrm{C}$ as described by the equation

$$
\left[\mathrm{O}_{2}\right]_{\max }=0.16 \text { to } 0.0037 T \text {, }
$$

where oxygen concentration $\left(\left[\mathrm{O}_{2}\right]_{\max }\right)$ is in $\mu \mathrm{mol} \mathrm{cm}{ }^{-3}$, temperature $(T)$ is in ${ }^{\circ} \mathrm{C}, r^{2}=0.80, F=21.16, P=0.01$, and $N=6$. Thus, for every $1^{\circ} \mathrm{C}$ rise in temperature, maximum oxygen content fell by $0.367 \mu \mathrm{mol} \mathrm{cm}{ }^{-3}$. The decline in maximum hemolymph oxygen content with temperature paralleled the decline in saturated seawater oxygen content and remained between $47.5 \%-49.4 \%$ of saturated seawater at these temperatures. Levels of $\left[\mathrm{O}_{2}\right]_{\max }$ in holding tanks and control chambers were around 95\% calculated maximum saturation, so maximum hemolymph concentration from samples taken near the heart was around $50 \%$ that of the seawater they were held in at temperatures between $0^{\circ}$ and $6^{\circ} \mathrm{C}$. Low values were always around $2 \%-3 \%$ of saturated seawater.

In terms of partial pressures, maximum levels were relatively constant in the hemolymph between $0^{\circ}$ and $6^{\circ} \mathrm{C}$ at values between 51 and $78 \mathrm{mmHg}$ (Table 3), showing that the decline in concentration is due to the maintenance of a constant $\mathrm{Po}_{2}$ gradient at sites of oxygen uptake. Minimum hemolymph $\mathrm{Po}_{2}$ values were always between 3.3 and $7.4 \mathrm{mmHg}$.

At $9^{\circ} \mathrm{C}$, hemolymph oxygen content collapsed such that no high values were recorded. Maximum levels obtained were under $12 \%$ saturated seawater. Minimum values were similar to those recorded at $0^{\circ}, 3^{\circ}$, and $6^{\circ} \mathrm{C}$. The same effect was observed when data are expressed as hemolymph $\mathrm{Po}_{2}$, with maximum levels declining to around $20 \mathrm{mmHg}$ at $9^{\circ} \mathrm{C}$ and with minimum values at $3.5 \mathrm{mmHg}$.

\section{Tissue Succinate Content}

Succinate contents of mantle tissues were elevated at $6^{\circ} \mathrm{C}(\sim 2.9$ $\mu \mathrm{mol} \mathrm{g}{ }^{-1}$ wet weight), compared with $0^{\circ}$ and $3^{\circ} \mathrm{C}(1-1.5 \mu \mathrm{mol}$ $\mathrm{g}^{-1}$ wet weight; Fig. 6). In the siphon, succinate accumulation occurred with a smaller temperature elevation and was elevated at $3^{\circ}$ and $6^{\circ} \mathrm{C}$ compared to $0^{\circ} \mathrm{C}$. In both tissues, succinate levels fell from $6^{\circ}$ to $9^{\circ} \mathrm{C}$. In the siphon, succinate levels rose after 3 $\mathrm{d}$ at that temperature, but in the group elevated to $10.5^{\circ} \mathrm{C}$, succinate levels were low in both tissues after $2 \mathrm{~d}$ of exposure.

\section{Discussion}

Laternula elliptica regulates its rate of $\mathrm{Mo}_{2}$ down to $\mathrm{Po}_{2}$ levels around $60-70 \mathrm{mmHg}$ in the inspired seawater. This indicates that none of the measurements of $\dot{M}_{2}$ here were affected by low $\mathrm{Po}_{2} \mathrm{~s}$ because $\mathrm{Po}_{2}$ values in these trials were not allowed to fall below $120 \mathrm{mmHg}$. Bivalve molluscs show a wide range of metabolic responses to reduced external $\mathrm{Po}_{2}$ (Bayne and Newell 1983), and the ability to regulate $\dot{M}_{2}$ exhibited by L. elliptica is not unusual.

The routine metabolic rate of $L$. elliptica at $0^{\circ} \mathrm{C}, 19.6 \mu \mathrm{mol}$ $\mathrm{O}_{2} \mathrm{~h}^{-1}$ for a 2-g tissue AFDM individual (6.42-g tissue dry mass, 58.4-g tissue wet mass), is within the range but low compared to other Antarctic bivalves and gastropods, most of which have $\dot{M O}_{2}$ values between 4 and $10.7 \mu \mathrm{mol} \mathrm{O}_{2} \mathrm{~g}^{-1}$ dry tissue mass $\mathrm{h}$ (Table 4 ). The data here are around three times lower than values for the same species measured by Peck and Conway (2000). This is probably because Peck and Conway (2000) measured $\dot{M}_{2}$ after only allowing the bivalves $10-24 \mathrm{~h}$ to acclimate to the holding systems, which is likely to have produced somewhat elevated rates. They also measured routine rates, which would have been elevated by feeding. In Antarctic marine ectotherms, feeding usually raises metabolism between 1.5 and 2.5 times standard or basal rates (Peck 1998). Another factor that may account for some of the difference is that they measured tissue dry mass by drying tissues to constant weight at $60^{\circ} \mathrm{C}$, which took between 36 and $60 \mathrm{~h}$. In this investigation, tissues were dried for a standard $24 \mathrm{~h}$. The difference in weights produced with these slightly different methods will account for some of the differences seen in tissue-mass-specific $\dot{M o}_{2}$. Peck and Conway (2000) also recently compared metabolic rates of 41 species of bivalve molluscs across temperature regimes from $0^{\circ}-30^{\circ} \mathrm{C}$. They compared routine metabolic rates measured at normal habitat temperatures and found that there was no ev- 


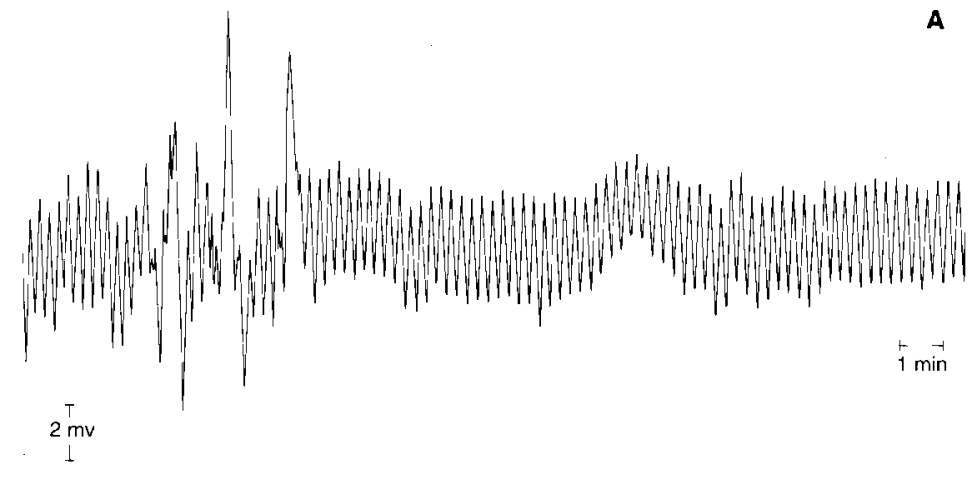

A
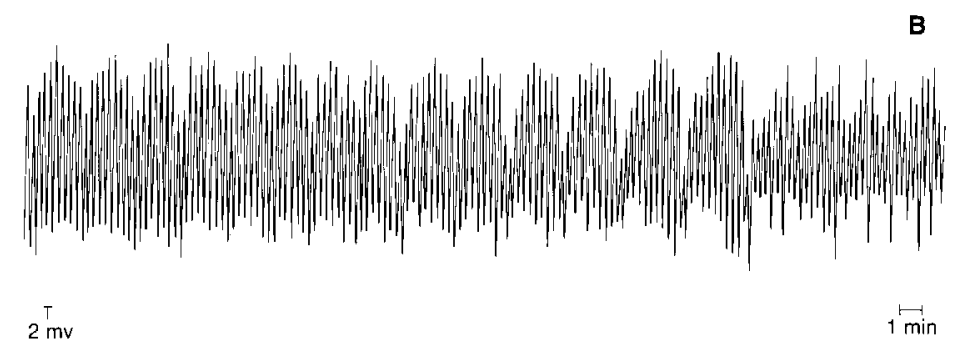

$1 \longdiv { \operatorname { m i n } }$

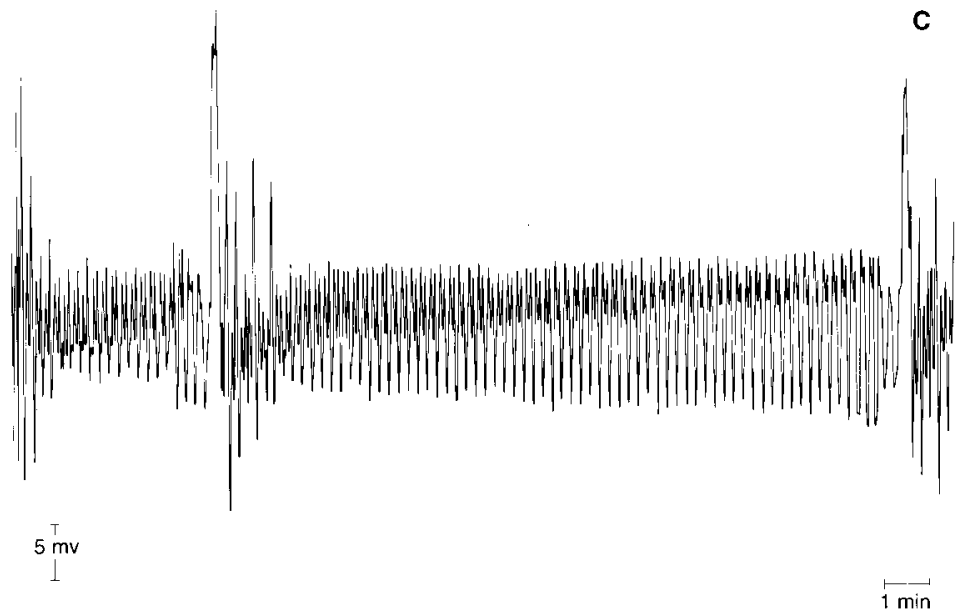

C

$\min$

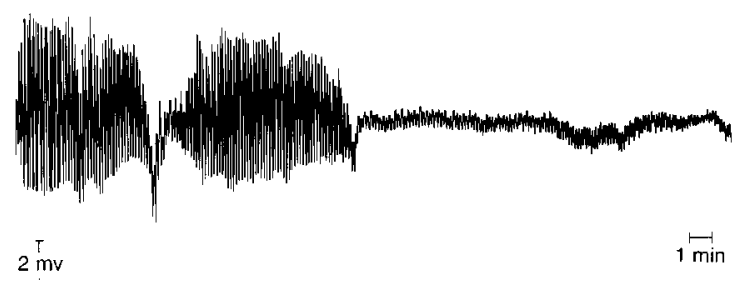

Figure 3. Impedance heartbeat traces for Laternula elliptica specimens held in the experimental regime. A, Typical trace at $0^{\circ} \mathrm{C}$ showing long periods of steady oscillation punctuated with short periods of disruption caused by bouts of activity (e.g., siphon contraction). Heartbeat rate was around $4 \mathrm{~min}^{-1}$ in this specimen. $B$, Trace for a specimen held at $0^{\circ} \mathrm{C}$ showing heartbeat contractions grouped into cycles of 2-3-min duration. $C$, Trace for one specimen at $0^{\circ} \mathrm{C}$ showing biphasic contraction. $D$, Trace for a specimen during the period when temperature was raised from $0^{\circ}$ to $3^{\circ} \mathrm{C}$. 


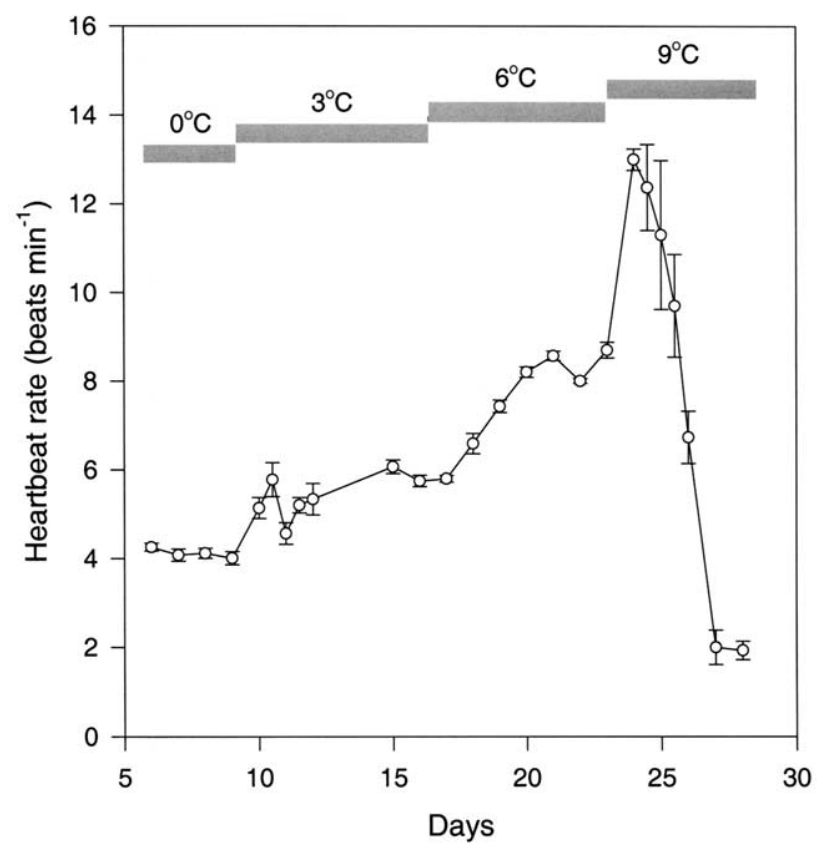

Figure 4. Laternula elliptica heartbeat rate (beats $\mathrm{min}^{-1}$ ) in relation to temperature. Values are means \pm SE for a group of four specimens. Bars indicate periods when temperatures were held at the values indicated above.

idence for elevated metabolism in polar species (whole-animal metabolic cold adaptation). Indeed, their data suggest that if there is a difference in the relationship between bivalve metabolism and temperature at low ambient temperatures, then polar species have lower $\dot{\mathrm{Mo}}_{2}$ rates than would be expected, although differences from the trend were only marginally significant. Their findings are similar to those for Antarctic fish by Clarke and Johnston (1999) who, in a comparison of all available metabolic-rate data for Perciform species, also showed no elevation of whole-animal metabolic rate at polar temperatures.

This poses an interesting conundrum. Recent considerations of cellular metabolic cold adaptation indicate whole-animal metabolism should be elevated at low temperatures (Pörtner et al. 2000). Maximum mitochondrial function rates show no temperature compensation between warm and cold species (Johnston et al. 1994, 1998; Guderley 1998; Pörtner et al. 1999a, 2000), although this character may differ between stenotherms and eurytherms (Pörtner et al. 2000). In fish, mitochondrial densities are elevated in low-temperature aerobic muscle to maintain whole-animal capacities for activity (Dunn 1988; Johnston et al. 1998). There is a cost associated with the maintenance of the intramitochondrial environment, because of the passive influx of protons through the mitochondrial membrane, driven by the proton gradient (Pörtner et al. 2000). Homeo- stasis in the face of proton leakage accounts for $25 \%-50 \%$ of standard metabolic rate (SMR) costs in rat hepatocytes and skeletal muscle (Brand 1990; Rolfe and Brand 1996), and similar costs would be expected in ectotherms (Pörtner et al. 2000). This leads directly to the conclusion that species with higher mitochondrial densities will have elevated metabolic costs. There are three possible solutions to the problem: (1) Proton leakage costs in mitochondria of low-temperature species are reduced compared to temperate analogues (Pörtner et al. 1998).

(2) Other physiological functions contributing to SMR are reduced to levels that compensate for the extra costs of mitochondrial homeostasis. Thus, other membrane pumping requirements and protein turnover costs may be markedly reduced in low-temperature species. (3) The extra costs are present but are too small to be observed at the whole-animal level.

There are insufficient data at present to identify which of these three possibilities accounts for the observed low wholeanimal metabolic rates in polar marine fish, and there is a clear need for more research here. There are currently no data on mitochondrial densities in polar molluscs, and it is possible that they are not elevated. If this were the case in invertebrates such as L. elliptica, the low metabolic rates found here would not require the above explanations, but the effects of temperature on mitochondrial function rates would still be important.

\section{Elevated Temperature and Metabolism}

As temperatures were increased progressively above $0^{\circ}$ to $3^{\circ} \mathrm{C}$ and then $6^{\circ}$ and $9^{\circ} \mathrm{C}$, L. elliptica metabolism increased to new levels. For $\dot{M o}_{2}$, acute $\mathrm{Q}_{10}$ values were all between 4 and 5,

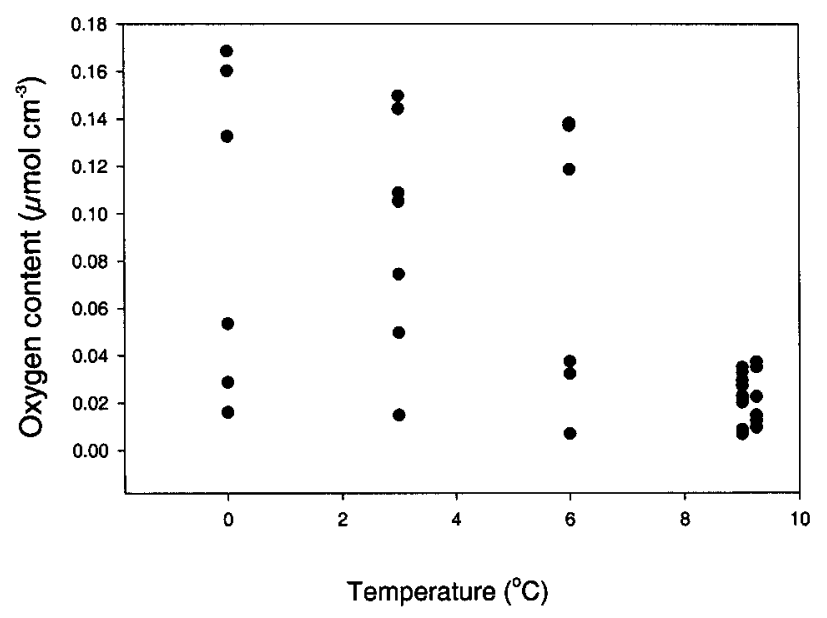

Figure 5. Laternula elliptica hemolymph oxygen content $\left(\mu \mathrm{mol} \mathrm{cm}{ }^{-3}\right)$ in relation to temperature. High values at $0^{\circ}, 3^{\circ}$, and $6^{\circ} \mathrm{C}$ are all $\sim 50 \%$ the level of oxygen content of the ambient seawater. Maximum values at $9^{\circ} \mathrm{C}$ were $12 \%$ of the content of ambient seawater. 
Table 3: Oxygenated and deoxygenated hemolymph oxygen partial pressures for Laternula elliptica at temperatures between $0^{\circ}$ and $9^{\circ} \mathrm{C}$

\begin{tabular}{lcc}
\hline Temperature $\left({ }^{\circ} \mathrm{C}\right)$ & Maximum $\mathrm{Po}_{2}$ & Minimum $\mathrm{Po}_{2}$ \\
\hline 0 & 78.4 & 7.4 \\
3 & 73.1 & 6.9 \\
6 & 75.6 & 3.3 \\
9 & 20.3 & 3.5 \\
\hline
\end{tabular}

Note. Values quoted are in $\mathrm{mmHg}$ and are the maximum and minimum figures obtained at each temperature.

whereas acclimated values were lower, between 2.2 and 3.4. The acclimated values are all well within the normal range for temperature effects on ectotherm metabolic rate (Clarke 1998; Peck, in press) and indicate no difference in temperature sensitivity of metabolism compared to temperate species. This finding is similar to that found for other Antarctic bivalves (Davenport 1988; Pörtner et al. 1999b), gastropods, and brachiopods (Peck 1989). It does, however, run contrary to the expectations concomitant with enhanced numbers of mitochondria, and the observations of high-temperature sensitivity in a few species (e.g., Forster et al. 1991). This is because mitochondrial proton leakage in L. elliptica has a high-temperature sensitivity (Pörtner et al. 1999a), and the limited data available suggest that high-temperature sensitivity of proton leakage may be characteristic of polar ectotherms (Hardewig et al. 1999). The limitations posed by high-temperature sensitivity in mitochondria of low-temperature species pose problems irrespective of whether densities are enhanced.

$\mathrm{Q}_{10}$ values for heartbeat rate were similar to those for $\dot{\mathrm{Mo}_{2}}$, ranging between 3.2 and 4.5. It was not possible to differentiate acute and acclimated responses in heartbeat rate. This, combined with the dramatic variations in heartbeat amplitude when temperatures were raised (Fig. 3), suggests that large effort was required to maintain physiological condition under temperature stress. This may be an indication that circulation and oxygen supply via the gills and the hemolymph may be limiting factors in tolerance to elevated temperature.

In an investigation of metabolic rate in response to raised temperature in the limpet Nacella concinna and the brachiopod Liothyrella uva, Peck (1989) found distinct peaks following a temperature change, which were followed by partial acclimation (sensu Precht et al. 1955) to new levels. A similar response was evident in L. elliptica for the temperature elevation from $3^{\circ}$ to $6^{\circ} \mathrm{C}$ and also possibly from $6^{\circ}$ to $9^{\circ} \mathrm{C}$. However, no acclimation was evident for the $\mathrm{Mo}_{2}$ response from $0^{\circ}$ to $3^{\circ} \mathrm{C}$. No peak followed by acclimation was observed in heartbeat rate at any temperature.

At $0^{\circ}, 3^{\circ}$, and $6^{\circ} \mathrm{C}$, hemolymph oxygen content varied widely from values around $3 \mathrm{mmHg}$ to over $75 \mathrm{mmHg}$. High values indicate the maximum oxygen content L. elliptica can attain at this site in these conditions. Low values are associated with periods of siphon closure (H. O. Pörtner, unpublished observation) and may be associated with a strategy for reducing costs of pumping water. With rising temperature, maximum oxygen content of the circulating hemolymph declined as a constant proportion of dissolved oxygen in the ambient seawater, approximately $50 \%$. This suggests that the L. elliptica were not capable of increasing the quantity of oxygen transferred across the gills, and it may indicate the limitation imposed by maximum transfer efficiency, although it should be noted that samples were collected from near the heart and not immediately after the hemolymph had passed through the gills.

\section{Temperature Limits and Critical Temperatures}

At $9^{\circ} \mathrm{C}$, where $50 \%$ L. elliptica mortality was observed within $7 \mathrm{~d}, \dot{\mathrm{Mo}}_{2}$ and heartbeat rate both peaked within $24 \mathrm{~h}$ of the temperature elevation, at values 3.3 times higher than the acclimated rates at $0^{\circ} \mathrm{C}$. On succeeding days, both measures collapsed such that between 5 and $6 \mathrm{~d}$ after moving to $9^{\circ} \mathrm{C}$, $\dot{\mathrm{Mo}}_{2}$ and heartbeat rate were below the same measures at $0^{\circ} \mathrm{C}$. Similar collapses of $\dot{\mathrm{M}}_{2}$ have been observed at upper lethal temperatures in other Antarctic gastropods and brachiopods (Peck 1989), sea urchins (Brockington and Peck, in press), and starfish (T. Hill and L. S. Peck, unpublished observation). Measures of hemolymph oxygen content collapsed above $6^{\circ} \mathrm{C}$ (Fig. 5 ), indicating that oxygen limitation was the likely mechanism setting the upper limit. On this basis, the long-term upper lethal temperature would be expected to be around $6^{\circ} \mathrm{C}$.

Previous studies have implicated oxygen supply as important in setting upper lethal limits, from observations of a transfer to anaerobic metabolism and the accumulation of anaerobic end products such as acetate, succinate, and octopine in tissues in both polar and temperate marine invertebrates (Zielinski and Pörtner 1996; Sommer et al. 1997; Pörtner et al. 1999b; Sommer and Pörtner 1999; van Dijk et al., in press). This transfer to anaerobic metabolism occurs close to the experimental upper lethal limit and has been termed the "critical temperature" (Pörtner et al. 1998, 2000). It identifies a physiological limit where oxygen supply and energy balance can no longer be maintained and indicates the maximum temperature for long-term survival in terms of weeks or months. Critical temperatures with transfers to anaerobic states have been observed to define both upper and lower limits for temperate marine species (Sommer et al. 1997; Pörtner et al. 1998).

Succinate measures here indicated that some tissues began accumulating anaerobic end products at $3^{\circ} \mathrm{C}$, and both tissues studied accumulated succinate at $6^{\circ} \mathrm{C}$. The reduced levels of succinate at $9^{\circ}$ and $10.5^{\circ} \mathrm{C}$ probably indicate a transfer to accumulation of other anaerobic end products of metabolism such as acetate. These data support the contention that the upper critical temperature for L. elliptica is around, or slightly below, $6^{\circ} \mathrm{C}$.

It has been suggested that the maximum metabolic rates 


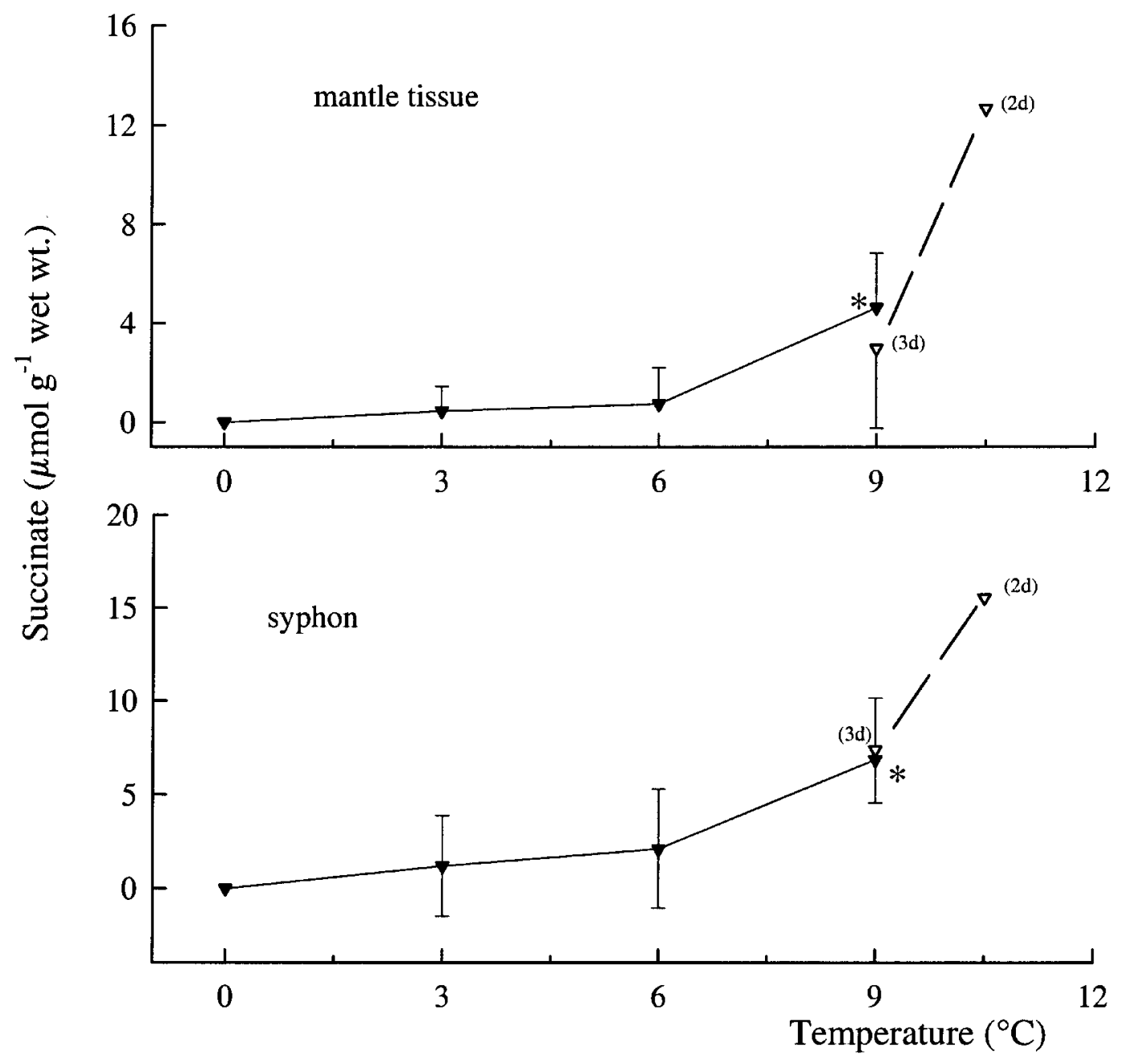

Figure 6. Succinate contents $\left(\mu \mathrm{mol} \mathrm{g}{ }^{-1}\right.$ wet weight) of Laternula elliptica mantle and siphon tissues at temperatures between $0^{\circ}$ and $10.5^{\circ} \mathrm{C}$. Values in the siphon were elevated at $3^{\circ} \mathrm{C}$ and were elevated in both tissues at $6^{\circ} \mathrm{C}$.

measured in studies such as this are set by limitations to oxygen supply mechanisms, which may indicate maximum physiological capacities. If this is so, the difference between this and acclimated resting metabolism in the normal temperature range is a measure of maximum aerobic potential that may be analogous to maximum aerobic capacity (Peck 1998, in press). The maximum elevations of $\dot{\mathrm{Mo}}_{2}$ and heartbeat rate of 3.3 and 3.4 times, respectively, values at $0^{\circ} \mathrm{C}$ fall within the range seen for Antarctic marine ectotherms but are high (Peck 1998). Values are usually in the range of 1.5 to 2.5 , and the figures for $L$. elliptica suggest it may have more metabolic flexibility than many other polar species. This assertion is also supported by the finding of an upper lethal temperature of $9^{\circ} \mathrm{C}$, which is one of the highest so far reported for an Antarctic species (Peck and Conway 2000).
The upper lethal temperatures defined here indicate shortterm survival limits, in terms of days, and animals may be able to survive shorter-term exposures to higher temperatures, although the value of such observations is questionable. Critical temperatures define the long-term survival limits for a species. Within this envelope, there will be functional and ecological limits, which will define more closely the temperature regimes and environments a given species can colonize. Thus, if the difference between standard metabolism at $0^{\circ} \mathrm{C}$ and maximum metabolism seen here at $9^{\circ} \mathrm{C}$ can be taken as an indication of maximum possible metabolic elevation, L. elliptica has a potential metabolic scope of 3.3 times values at $0^{\circ} \mathrm{C}$, which would equate to an actual scope of around $45 \mu \mathrm{mol} \mathrm{O}$ animal $^{-1} \mathrm{~h}^{-1}$ for a standard 2-g tissue AFDM animal. From Figure 2, it is clear that this potential scope would be reduced to $35-40 \mu \mathrm{mol}$ 
Table 4: Oxygen consumption rates $\left(\dot{\mathrm{Mo}}_{2}\right)$ for Antarctic bivalve molluscs

\begin{tabular}{lrl}
\hline Species & $\dot{M o}_{2}$ & References \\
\hline Bivalve molluscs: & & \\
Cyclocardia astartoides & 1.87 & Peck and Conway 2000 \\
Gaimardia trapesina & 9.07 & Ralph and Maxwell 1977b \\
Laternula elliptica & 6.44 & Ahn and Shim 1998 \\
L. elliptica & 10.70 & Peck and Conway 2000 \\
L. elliptica & 3.05 & This study \\
Limopsis marionensis & 4.56 & Pörtner et al. 1999b \\
Yoldia eightsi & 4.46 & Davenport 1988 \\
Gastropod molluscs: & & \\
$\quad$ Nacella concinna & 6.86 & Houlihan and Allan 1982 \\
N. concinna & 2.09 & Peck 1989 \\
Pellilitorina setosa & 7.89 & Houlihan and Allan 1982 \\
Trophon sp. & 5.23 & Houlihan and Allan 1982 \\
Brachiopods: & & \\
$\quad$ Liothyrella uva & 1.37 & Peck et al. 1987 \\
L. uva & 1.80 & Peck 1989 \\
\hline
\end{tabular}

Note. $\dot{M}_{2}=\mu \mathrm{mol} \mathrm{O} \mathrm{g}^{-1}$ dry tissue mass $\mathrm{h}^{-1}$. Values shown are for measures made at temperatures between $0^{\circ}$ and $1^{\circ} \mathrm{C}$. Where conversions have been made from data expressed as tissue wet mass or AFDM, the values obtained for those measures in this study have been used.

$\mathrm{O}_{2}$ animal $^{-1} \mathrm{~h}^{-1}$ at $3^{\circ} \mathrm{C}$ and $25-30 \mu \mathrm{mol} \mathrm{O}_{2}$ animal $^{-1} \mathrm{~h}^{-1}$ at $6^{\circ} \mathrm{C}$. Aerobic capacity is required for work. At some stage as temperature rises, the remaining aerobic scope will be insufficient to support either a critical function, or a combination of critical functions, and this will define the functional limit for the species. Such limits will be within the envelope set by critical temperatures. The physiological temperature envelopes for polar ectotherms are small, usually between $5^{\circ}$ and $10^{\circ} \mathrm{C}$ (Somero and DeVries 1967; Peck and Conway 2000), and the species living there are termed "stenothermal." Clearly, their functional survival windows are even smaller, making them highly susceptible in the face of environmental change.

\section{Acknowledgments}

We thank the members of the British Antarctic Survey station at Rothera for support during the practical aspects of the work. Special thanks are due to Rob Wood and Alice Chapman for assistance in specimen collection. S. Leighton provided great help in maintaining cooling equipment in top-notch condition. We are also indebted to A. Clarke for comments on the manuscript.

\section{Literature Cited}

Ahn I.-Y. 1994. Ecology of the Antarctic bivalve Laternula elliptica (King and Broderip) in Collins Harbour, King George
Island: benthic environment and adaptive strategy. Mem Natl Inst Polar Res Spec Issue 50:1-10.

. 1997. Feeding ecology of the Antarctic bivalve Laternula elliptica (Laternulidae) in Marian Cove and vicinity, King George Island during one austral summer. Pp. 142-151 in B. Battaglia, J. Valencia, and D.W. Walton, eds. Antarctic Communities: Species, Structure and Survival. Cambridge University Press, Cambridge.

Ahn I.-Y. and J.H. Shim. 1998. Summer metabolism of the Antarctic clam, Laternula elliptica (King and Broderip) in Maxwell Bay, King George Island and its implications. J Exp Mar Biol Ecol 224:253-264.

Bayne B.L. and R.C. Newell. 1983. Physiological energetics of marine molluscs. Pp. 407-516 in A.S.M. Saleuddin and K.M. Wilbur, eds. The Mollusca. Vol. 4. Academic Press, London.

Brand M.D. 1990. The contribution of the leak of protons across the mitochondrial inner membrane to standard metabolic rate. J Theor Biol 145:267-286.

Brey T. and A. Mackensen. 1997. Stable isotopes prove shell growth bands in the Antarctic bivalve Laternula elliptica to be formed annually. Polar Biol 17:465-468.

Brockington S. and A. Clarke. 2001. The relative influence of temperature and food on the metabolism of a marine invertebrate. J Exp Mar Biol Ecol 258:87-99.

Brockington S. and L.S. Peck. In press. Critical temperatures and metabolism in the Antarctic urchin Sterechinus neumayeri. Mar Biol.

Buchan P., L.S. Peck, and N.J. Tublitz. 1988. A light, portable apparatus for the assessment of invertebrate heartbeat rate. J Exp Biol 136:495-498.

Clarke A. 1998. Temperature and energetics: an introduction to cold ocean physiology. Pp. 3-30 in H.O. Pörtner and R. Playle, eds. Cold Ocean Physiology. Society for Experimental Biology Seminar Series 66. Cambridge University Press, Cambridge.

Clarke A. and N. Johnston. 1999. Scaling of metabolic rate and temperature in teleost fish. J Anim Ecol 68:893-905.

Davenport J. 1988. Oxygen consumption and ventilation rate at low temperatures in the Antarctic protobranch bivalve mollusc Yoldia (=Aequiyoldia) eightsii (Courthouy). Comp Biochem Physiol 90A:511-513.

Dunn J.F. 1988. Low-temperature adaptation of oxidative energy production in cold-water fishes. Can J Zool 66:1098-1104.

Forster M.E., C.E. Franklin, H.H. Taylor, and W. Davison. 1991. The aerobic scope of an Antarctic fish, Pagothenia borchgrevinki and its significance for metabolic cold adaptation. Polar Biol 8:155-159.

Guderley H. 1998. Temperature and growth as modulators of the metabolic capacities of fish muscle. Pp. 58-87 in H.O. Pörtner and R. Playle, eds. Cold Ocean Physiology. Society for Experimental Biology Seminar Series 66. Cambridge University Press, Cambridge.

Hardewig I., L.S. Peck, and H.O. Pörtner. 1999. Thermal sen- 
sitivity of mitochondrial function in the Antarctic notothenioid Lepidonotothen nudifrons. J Comp Physiol 169: 597-604.

Houlihan D.F. and D. Allan. 1982. Oxygen consumption of some Antarctic and British gastropods: an evaluation of cold adaptation. Comp Biochem Physiol 73A:383-387.

Johnston I.A. and A.F. Bennet, eds. 1996. Animals and Temperature: Phenotypic and Evolutionary Adaptation. Society for Experimental Biology Seminar Series 59. Cambridge University Press, Cambridge.

Johnston I.A., J. Calvo, H. Guderley, D. Fernandez, and L. Palmer. 1998. Latitudinal variation in the abundance and oxidative capacities of muscle mitochondria in perciform fishes. J Exp Biol 201:1-12.

Johnston I.A., H.E. Guderley, C.E. Franklin, T. Crockford, and C. Kamunde. 1994. Are mitochondria subject to evolutionary temperature adaptation? J Exp Biol 195:293-306.

Peck L.S. 1989. Temperature and basal metabolism in two Antarctic marine herbivores. J Exp Mar Biol Ecol 127:1-12.

- 1998. Feeding, metabolism and metabolic scope in Antarctic marine ectotherms. Pp. 365-390 in H.O. Pörtner and R. Playle, eds. Cold Ocean Physiology. Society for Experimental Biology Seminar Series 66. Cambridge University Press, Cambridge.

- 2002. Ecophysiology of Antarctic marine ectotherms: limits to life. Keynote contribution, Scientific Committee on Antarctic Research, Ecology of the Antarctic Sea-Ice Zone symposium, Bremerhaven, June 1999. Polar Biol 25:31-40.

Peck L.S., A. Clarke, and L.J. Holmes. 1987. Summer metabolism and seasonal changes in biochemical composition of the Antarctic brachiopod Liothyrella uva (Broderip, 1833). J Exp Mar Biol Ecol 114:85-97.

Peck L.S. and L.Z. Conway. 2000. The myth of metabolic cold adaptation: oxygen consumption in stenothermal Antarctic bivalves. Pp. 441-450 in E. Harper and A.J. Crame, eds. Evolutionary Biology of the Bivalvia. Geol Soc Lond Spec Publ 177. Cambridge University Press, Cambridge.

Peck L.S. and R.F. Uglow. 1990. Two methods for the assessment of the oxygen content of small samples of seawater. J Exp Mar Biol Ecol 141:53-62.

Pörtner H.O., I. Hardewig, and L.S. Peck. 1999a. Mitochondrial function and critical temperature in the Antarctic bivalve Laternula elliptica. Comp Biochem Physiol 124:179-189.

Pörtner H.O., I. Hardewig, F.J. Sartorius, and P. van Dijk. 1998. Energetic aspects of cold adaptation: critical temperatures in metabolic, ionic and acid base regulation? Pp. 88-120 in H.O. Pörtner and R. Playle, eds. Cold Ocean Physiology. Society for Experimental Biology Seminar Series 66. Cambridge University Press, Cambridge.

Pörtner H.O., L.S. Peck, S. Zielinski, and L.Z. Conway. 1999 b. Intracellular $\mathrm{pH}$ and energy metabolism in the highly stenothermal Antarctic bivalve Limopsis marionensis as a function of ambient temperature. Polar Biol 22:17-30.
Pörtner H.O. and R.C. Playle, eds. 1998. Cold Ocean Physiology. Society for Experimental Biology Seminar Series 66. Cambridge University Press, Cambridge.

Pörtner H.O., P.L.M. van Dijk, I. Hardewig, and A. Sommer. 2000. Levels of metabolic cold adaptation: tradeoffs in eurythermal and stenothermal ectotherms. Pp. 109-122 in W. Davison and C. Howard Williams, eds. Antarctic Ecosystems: Models for Wider Ecological Understanding. Caxton, Christchurch, New Zealand.

Precht H., J. Christophersen, and H. Hensel. 1955. Temperatur und Leben. Springer, Berlin.

Ralph R. and J.H.G. Maxwell. 1977a. Growth of two Antarctic lamellibranchs: Adamussium colbecki and Laternula elliptica. Mar Biol 42:171-175.

$1977 b$. The oxygen consumption of the Antarctic lamellibranch Gaimardia trapesina trapesina in relation to cold adaptation in polar marine invertebrates. Br Antarct Surv Bull 45:41-46.

Rolfe D.F.S. and M.D. Brand. 1996. Contribution of mitochondrial proton leak to skeletal muscle respiration and to standard metabolic rate. Am J Physiol 271:C1380-C1389.

Somero G.N., E. Dahlhoff, and J.J. Lin. 1996. Stenotherms and eurytherms: mechanisms establishing thermal optima and tolerance ranges. Pp. 53-78 in H.O. Pörtner and R. Playle, eds. Cold Ocean Physiology. Society for Experimental Biology Seminar Series 66. Cambridge University Press, Cambridge.

Somero G.N. and A.L. DeVries. 1967. Temperature tolerance of some Antarctic fishes. Science 156:257-258.

Somero G.N., P.A. Fields, G.E. Hofmann, R.B. Weinstein, and H. Kawall. 1998. Cold adaptation and stenothermy in Antarctic notothenioid fishes: what has been gained and what has been lost? Pp. 97-109 in G. diPrisco, E. Pisano, and A. Clarke, eds. Fishes of Antarctica: A Biological Overview. Springer, Milan.

Sommer A., B. Klein, and H.O. Pörtner. 1997. Temperature induced anaerobiosis in two populations of the polychaete worm Arenicola marina. J Comp Physiol 167B:25-35.

Sommer A. and H.O. Pörtner. 1999. Exposure of Arenicola marina (L.) to extreme temperatures: adaptive flexibility of a boreal and subpolar population. Mar Ecol Prog Ser 181: 215-226.

van Dijk P.L.M., C. Tesch, I. Hardewig, and H.O. Pörtner. 1999. Physiological disturbances at critically high temperatures: a comparison between stenothermal Antarctic, and eurythermal temperate eelpouts (Zoarcidae). J Exp Biol 202: 3611-3621.

Zielinski S. and H.O. Pörtner. 1996. Energy metabolism and ATP free-energy change of the intertidal worm, Sipunculus nudus, below a critical temperature. J Comp Physiol 166B: 492-500. 